UDC 616-056.7-07

doi: https://doi.org/10.15407/ubj88.05.096

\title{
DETERMINATION OF FREQUENCIES OF ALLELES, ASSOCIATED WITH THE PSEUDODEFICIENCY OF LYSOSOMAL HYDROLASES, IN POPULATION OF UKRAINE
}

\author{
N. V. OLKHOVYCH, N. G. GOROVENKO
}

State Institute of Genetic and Regenerative Medicine, NAMS of Ukraine, Kyiv;
e-mail: nolhovich@gmail.com

The pseudodeficiency of lysosomal hydrolases described as a significant reduction in enzyme activity in vitro in clinically healthy individuals, can lead to diagnostic errors in the process of biochemical analysis of lysosomal storage disease in case of its combination with pathology of another origin. Pseudodeficiency is mostly caused by some non-pathogenic changes in the corresponding gene. These changes lead to the in vitro lability of the enzyme molecule, whereas in vivo the enzyme retains its functional activity. To assess the prevalence of the most common lysosomal hydrolases pseudodeficiency alleles in Ukraine, we have determined the frequency of alleles c.1055A>G and c. ${ }^{*} 96 A>G$ in the ARSA gene, substitutions c.739C $>T(R 247 W)$ and c.745C $>T$ (R249W) in the HEXA gene, c.1726G>A (G576S) and c.2065G>A (E689K) in the GAA gene, c.937G>T (D313Y) in the GLA1 gene and c.898G>A (A300T) in the IDUA gene in a group of 117 healthy individuals from different regions of the country and 14 heterozygous carriers of pathogenic mutations in the HEXA gene (parents of children with confirmed diagnosis of Tay-Sachs disease). The total frequency of haplotypes, associated with arylsulfatase A pseudodeficiency, in healthy people in Ukraine (c.1055G/c.*96G and c.1055G/c.*96A haplotypes) was $10.3 \%$. The frequency of c.739C $>T(R 247 \mathrm{~W})$ allele, associated with hexosaminidase A pseudodeficiency, among Tay-Sachs carriers from Ukraine was $7.1 \%$. The total frequency of $\alpha$-glucosidase pseudodeficiency haplotypes in healthy individuals in Ukraine (c.1726A/c.2065A and c.1726G/ c.2065A haplotypes) was 2.6\%. No person among examined individuals with the substitution c.937G>T (D313Y) in the GLA1 gene and c.898G>A (A300T) in the IDUA gene was found. The differential diagnostics of lysosomal storage diseases requires obligatory determination of the presence of the pseudodeficiency alleles, particularly the ones with high incidence in the total population. Ignoring phenomenon of pseudodeficiency may lead to serious diagnostic errors.

Key words: lysosomal hydrolases, pseudodeficiency of the enzyme, allele frequency.

I $\mathrm{n}$ most cases, the hereditary deficiency of lysosomal hydrolases is associated with the development of severe neurodegenerative diseases lysosomal storage disorders [1]. However, some individuals remain clinically healthy despite a significant decrease in the activity of a certain enzyme, determined by standard techniques. This phenomenon is called "pseudodeficiency" of the enzyme [2]. In practice, this situation usually refers not to the absolute deficiency of the enzyme activity but, rather, to a decrease to the level which is lower than that for heterozygous carriers, thus resulting in impossibility of distinguishing between such individuals and patients with lysosomal storage disorders. The pseudodeficiency phenomenon is described not solely for lysosomal hydrolases, however, it is more common for this group of enzymes.
It was established that in most cases, the pseudodeficiency of lysosomal hydrolases is caused by some polymorphic changes in the corresponding gene [2]. Usually, these changes are non-pathogenic and lead to in vitro lability of the enzyme molecule, whereas in vivo the enzyme retains functional activity. Such changes may be inherited either independently, i.e. in the absence of any other changes in the corresponding gene, or in the combination with pathogenic mutations. In the first case, any person in the entire population, regardless of the aggravation with pathogenic mutations of the corresponding gene, may carry the pseudodeficiency allele and express the decreased enzyme activity at biochemical examination [3]. As for the other case, related to the combination of inheritance and pathogenic mutations, pseudodeficiency of enzyme activity is mostly 
manifested in heterozygous carriers of pathogenic mutations [4]. Both situations can lead to serious errors during biochemical diagnostics of lysosomal storage disorders when the enzyme pseudodeficiency and pathology of some other genesis are combined. Therefore, to avoid false diagnosis, if a decreased activity of the corresponding enzyme was determined in a patient, the biochemical test of lysosomal enzymes, for which pseudodeficiency had been established, should include the determination of pseudodeficiency alleles. It is also essential to assess the pathogenicity of the identified genetic changes at the interpretation of the proband's genetic analysis.

The most striking feature of the phenomenon of lysosomal enzymes pseudodeficiency is rather high incidence in the total population. For instance, population-based studies in different countries showed that 5 to $17 \%$ of the $A R S A$ gene variants in the population are represented by the variant associated with arylsulfatase A pseudodeficiency [5-11]. At the same time, other pseudodeficiencies, such as hexasominidase $\mathrm{A}$ and $\mathrm{B}, \beta$-mannosidase or $\beta$-galactosidase pseudodeficiency, occur quite rarely; at present only single cases of such changes have been described [12-14]. Therefore, to elaborate the most efficient algorithms for laboratory analysis for differential diagnostics of lysosomal storage disorders in a specific population, the frequency of alleles of pseudodeficiency of lysosomal hydrolases in this population should be taken into consideration.

Our work was aimed at determining the incidences of the most widespread alleles in genes $A R S A$, HEXA, GAA, GLAI and IDUA, which cause the arylsulfatase $\mathrm{A}, \beta$-hexasominidase $\mathrm{A}, \alpha$-galactosidase, $\alpha$-L-iduronidase and $\alpha$-glucosidase pseudodeficiency in the Ukrainian population.

\section{Materials and Methods}

The studies were conducted using blood samples from 117 unrelated volunteers with no signs of lysosomal storage disorders in their clinical history from all the regions of Ukraine and 14 heterozygous carriers of pathogenic mutations in the HEXA gene (parents of children with confirmed diagnosis of Tay-Sachs disease).

All participants gave informed consent for the study prior to the procedure of obtaining their blood samples.

Genomic DNA was isolated from whole peripheral blood with EDTA using Neogene commercial sets (Ukraine). The determination of c. $1049 \mathrm{~A}>\mathrm{G}$ and c.*96 $\mathrm{A}>\mathrm{G}$ variants of $A R S A$ gene was performed by PCR method with subsequent RFLP-analysis [8]. The design of primers and the conditions of RFLP-analysis are presented in Table 1 .

Analysis of the products was performed by electrophoresis in $8 \%$ PAAG followed by staining with ethidium bromide solution.

Determination of substitutions c.739C $>\mathrm{T}$ $(\mathrm{R} 247 \mathrm{~W})$ and c.745C $>\mathrm{T}(\mathrm{R} 249 \mathrm{~W})$ in HEXA gene, c. $1726 \mathrm{G}>\mathrm{A}(\mathrm{G} 576 \mathrm{~S})$ and c.2065G $>\mathrm{A}(\mathrm{E} 689 \mathrm{~K})$ in GAA gene, c.937G $>\mathrm{T}$ (D313Y) in GLA1 gene and c. $898 \mathrm{G}>\mathrm{A}$ (A300T) in IDUA gene was performed by the allele-specific amplification method. The design of primers for allele-specific amplification was developed by Neogene (Ukraine) (Table 2).

Analysis of the products was performed by electrophoresis in $2 \%$ agarose gel followed by staining with ethidium bromide solution.

Arlequin 3.5 software was used to assess allele frequencies, their correspondence to the HardyWeinberg equilibrium, value of linkage disequilib-

Table 1. Design of primers and conditions of RFLP-analysis of c.1049A>G and c.*96 A>G of ARSA gene variants

\begin{tabular}{|c|c|c|c|c|c|}
\hline Allele & Primers & $\begin{array}{l}\text { Annea- } \\
\text { ling } \\
\text { tempera- } \\
\text { ture }\end{array}$ & $\begin{array}{l}\text { Fragment } \\
\text { size }\end{array}$ & $\begin{array}{l}\text { Restriction } \\
\text { endonuc- } \\
\text { lease }\end{array}$ & $\begin{array}{l}\text { Presence of } \\
\text { a restriction } \\
\text { site in case } \\
\text { of genetic } \\
\text { replacement }\end{array}$ \\
\hline \multirow{2}{*}{ c. $1049 \mathrm{~A}>\mathrm{G}$} & 5'-TTGATGGCGAACTGAGTGAC-3' & \multirow{2}{*}{$58^{\circ} \mathrm{C}$} & \multirow{2}{*}{$277 \mathrm{bp}$} & \multirow{2}{*}{ BsrI } & \multirow{2}{*}{+} \\
\hline & 5'-CAGTGCAGGAGGCACTGAGG-3' & & & & \\
\hline \multirow{2}{*}{ c. $* 96 \mathrm{~A}>\mathrm{G}$} & 5'-GGTTTGTGCCTGATAACTTA-3' & \multirow{2}{*}{$61{ }^{\circ} \mathrm{C}$} & \multirow{2}{*}{114 bp } & \multirow{2}{*}{ DdeI } & \multirow{2}{*}{+} \\
\hline & 5'-TTCCTCATTCGTACCACAGG-3' & & & & \\
\hline
\end{tabular}


Ta ble 2. Design of primers for allele-specific amplification

\begin{tabular}{|c|c|c|c|}
\hline Gene & Allele & Primers & Fragment size \\
\hline \multirow[t]{8}{*}{$H E X A$} & \multirow{2}{*}{ c.739C } & 5'-TTCCCAGGTGGAAGAAGTCG-3' & \multirow{4}{*}{$228 \mathrm{bp}$} \\
\hline & & 5'-GAAGGAGGTCATTGAATACGCAC-3' & \\
\hline & \multirow{2}{*}{ c.739T } & 5'-TTCCCAGGTGGAAGAAGTCG-3' & \\
\hline & & 5'-GAAGGAGGTCATTGAATACGCAT-3' & \\
\hline & \multirow{2}{*}{ c. $745 \mathrm{C}$} & 5'-TTCCCAGGTGGAAGAAGTCG-3' & \multirow{4}{*}{$224 \mathrm{bp}$} \\
\hline & & 5'-GAGGTCATTGAATACGCACGGCTCC-3' & \\
\hline & \multirow{2}{*}{ c.745T } & 5'-TTCCCAGGTGGAAGAAGTCG-3' & \\
\hline & & 5'-GAGGTCATTGAATACGCACGGCTCT-3' & \\
\hline \multirow[t]{8}{*}{ GAA } & \multirow{2}{*}{ c. $1726 \mathrm{G}$} & 5'-GCAGTGGAGATGATTACCCAGGTTC-3' & \multirow{4}{*}{306 bp } \\
\hline & & 5'-GCG ATG GCT TCG GTC AGG Cㅁ-3' & \\
\hline & \multirow{2}{*}{ c. $1726 \mathrm{~A}$} & 5'-GCAGTGGAGATGATTACCCAGGTTC-3' & \\
\hline & & 5'-GCG ATG GCT TCG GTC AGG CT-3' & \\
\hline & \multirow{2}{*}{ c. $2065 \mathrm{G}$} & 5'-TGG CCT CCA CAG CTT GAT TT-3' & \multirow{4}{*}{$521 \mathrm{bp}$} \\
\hline & & 5'-CA GGA GCC GTA CAG CTT CAG C $\underline{\text { G-3' }}$ & \\
\hline & \multirow{2}{*}{ c. $2065 \mathrm{~A}$} & 5'-TGG CCT CCA CAG CTT GAT TT-3' & \\
\hline & & 5'-CA GGA GCC GTA CAG CTT CAG CA- $3^{\prime}$ & \\
\hline \multirow[t]{4}{*}{ GLA1 } & \multirow{2}{*}{ c. $937 \mathrm{G}$} & 5'-ACCTGTCTAAGCTGGTACCCTT-3' & \multirow{4}{*}{$88 \mathrm{bp}$} \\
\hline & & 5'-CTCAAGCCAAAGCTCTCCTTCAGG-3' & \\
\hline & \multirow{2}{*}{ c. $937 \mathrm{~T}$} & 5'-ACCTGTCTAAGCTGGTACCCTT-3' & \\
\hline & & 5'-CTCAAGCCAAAGCTCTCCTTCAGT-3' & \\
\hline \multirow[t]{4}{*}{ IDUA } & \multirow{2}{*}{ c. $898 \mathrm{G}$} & 5'-TCCATCTCCATCCTGGAGCAG-3' & \multirow{4}{*}{$113 \mathrm{bp}$} \\
\hline & & 5'-CAGCCCACCAGCGGGTCCGㄷ-3' & \\
\hline & \multirow{2}{*}{ c. $898 \mathrm{~A}$} & 5'-TCCATCTCCATCCTGGAGCAG-3' & \\
\hline & & 5'-CAGCCCACCAGCGGGTCCGT-3' & \\
\hline
\end{tabular}

The allele-specific nucleotides are underlined.

rium, and incidences of haplotypes. The significance level $p=0.05$ was used to assess the statistical significance of the differences.

\section{Results and Discussion}

To date, the pseudodeficiency of at least eight lysosomal hydrolases: arylsulfatase $\mathrm{A}$, $\beta$-hexosaminidase $\mathrm{A}$ and $\mathrm{B}, \beta$-hexosaminidase $\mathrm{A}$, $\alpha$-galactosidase, $\beta$-galactosidase, $\alpha$-L-iduronidase, $\alpha$-glucosidase, and $\beta$-mannosidase has been established (Table 3).

We studied the incidence of polymorphic alleles of genes, associated with the pseudodeficiency of five lysosomal enzymes, namely alleles c.1055A $>\mathrm{G}$ and c.*96A $>\mathrm{G}$ in $A R S A$ gene and alleles c.739C $>\mathrm{T}$ and c. $745 \mathrm{C}>\mathrm{T}$ in $H E X A$ gene, as alleles with the highest incidence rate in many populations, as well as alleles c. $1726 \mathrm{G}>\mathrm{A}$ and c. $2065 \mathrm{G}>\mathrm{A}$ in $G A A$ gene,c. $937 \mathrm{G}>\mathrm{T}$ in GLA1 gene and c.898G $>\mathrm{A}$ in IDUA gene. The latter three have been chosen due to their relevance to early and accurate diagnostics of the corresponding diseases, related to specific enzyme replacement therapy.

The alleles of the pseudodeficiency of other lysosomal enzymes, such as $\beta$-galactosidase, $\beta$-mannosidase and $\beta$-hexosaminidase $A$ and $B$, were not studied in this work.

Arylsulfatase A pseudodeficiency. It is known that alleles c. $1055 \mathrm{~A}>\mathrm{G}$ and c. ${ }^{*} 96 \mathrm{~A}>\mathrm{G}$ in $A R S A$ gene are the most common cause of the arylsulfatase A pseudodeficiency in most populations [8]. They have been discovered in individuals both with and without pathogenic mutations in this gene. Therefore, our assessment of the frequency of these alleles in 
Table 3. Alleles, which are associated with the lysosomal hydrolases pseudodeficiency

\begin{tabular}{|c|c|c|c|c|}
\hline Lysosomal enzyme & $\begin{array}{l}\text { Disease, caused by the } \\
\text { enzymatic deficiency }\end{array}$ & Gene & $\begin{array}{l}\text { Alleles, associated with } \\
\text { enzyme pseudodeficiency }\end{array}$ & Ref. \\
\hline $\begin{array}{l}\text { Arylsulfatase A } \\
\text { (EC 3.1.6.1) }\end{array}$ & $\begin{array}{l}\text { Metachromatic } \\
\text { leukodystrophy }\end{array}$ & $A R S A$ & $\begin{array}{l}\text { c. } 1055 \mathrm{~A}>\mathrm{G}(\mathrm{N} 350 \mathrm{~S}) \\
\text { c. }{ }^{*} 96 \mathrm{~A}>\mathrm{G}(\text { polyA loss }) \\
\mathrm{c} .1462 \mathrm{C}>\mathrm{T}(\mathrm{Q} 488 \mathrm{X})^{*} \\
\mathrm{c} .1150 \mathrm{G}>\mathrm{A}(\mathrm{E} 384 \mathrm{~K})^{*} \\
\mathrm{c} .1136 \mathrm{C}>\mathrm{T}(\mathrm{P} 379 \mathrm{~L})^{*} \\
\text { c. } 511 \mathrm{G}>\mathrm{A}(\mathrm{D} 171 \mathrm{~N})^{*}\end{array}$ & $\begin{array}{l}{[3]} \\
{[15]} \\
{[16]} \\
{[17]} \\
{[15]}\end{array}$ \\
\hline $\begin{array}{l}\beta \text {-hexosaminidase } \\
\text { A (EC 3.2.1.52) }\end{array}$ & Tay-Sachs disease & $H E X A$ & $\begin{array}{l}\text { c.739C }>\mathrm{T}(\mathrm{R} 247 \mathrm{~W}) \\
\text { c.745C }>\mathrm{T}(\mathrm{R} 249 \mathrm{~W})\end{array}$ & [4] \\
\hline $\begin{array}{l}\alpha \text {-glucosidase } \\
\text { (EC 3.2.1.20) }\end{array}$ & Pompe disease & GAA & $\begin{array}{l}\text { c. } 1726 \mathrm{G}>\mathrm{A}(\mathrm{G} 576 \mathrm{~S}) \\
\text { c.2065G }>\text { A (E689K) }\end{array}$ & [18] \\
\hline $\begin{array}{l}\alpha \text {-galactosidase } \\
\text { (EC 3.2.1.22) }\end{array}$ & Fabry disease & GLAl & c.937G>T (D313Y) & [19] \\
\hline $\begin{array}{l}\beta \text {-galactosidase } \\
\text { (EC 3.2.1.23) }\end{array}$ & GM1-gangliosidosis & GLB1 & $\begin{array}{l}\text { c.1561T }>C(C 521 R)^{*} \\
\text { c.1594A }>\text { G (S532G) } \\
\text { c.1783A }>\text { T (R595W) }\end{array}$ & [14] \\
\hline $\begin{array}{l}\alpha \text {-L-iduronidase } \\
\text { (EC 3.2.1.76) }\end{array}$ & $\begin{array}{l}\text { Type I mucopolysaccha- } \\
\text { ridosis (Hurler's syndrome) }\end{array}$ & $I D U A$ & c.898G >A (A300T) & [20] \\
\hline $\begin{array}{l}\beta \text {-mannosidase } \\
\text { (EC 3.2.1.25) }\end{array}$ & $\beta$-mannosidosis & $M A N B A$ & c.1922G>A (R641H)* & [13] \\
\hline $\begin{array}{l}\text { B-hexosaminidase } \mathrm{A} \text { and } \mathrm{B} \\
\text { (EC 3.2.1.52) }\end{array}$ & Sandhoff disease & $H E X B$ & 18 bp INS (HEX PARIS)* & [12] \\
\hline
\end{tabular}

*Described single cases

the Ukrainian population included determination of the frequency of alleles c. $1055 \mathrm{~A}>\mathrm{G}$ and c. ${ }^{*} 96 \mathrm{~A}>\mathrm{G}$ in ARSA gene in 117 healthy individuals from different regions of the country.

The total incidence of alleles was found to be $5.56 \%$ for the substitution of c. $1055 \mathrm{~A}>\mathrm{G}$ and $4.7 \%$ for the substitution of $\mathrm{c}{ }^{*} 96 \mathrm{~A}>\mathrm{G}$. The genotype distribution among the investigated individuals corresponded to Hardy-Weinberg equilibrium for both substitutions $(P>0.05)$. It is known that in the vast majority of cases these two alleles are inherited together. A significantly linkage disequilibrium of alleles c. $1055 \mathrm{~A}>\mathrm{G}$ and c. $* 96 \mathrm{~A}>\mathrm{G}\left(r^{2}=0.84, P<0.05\right)$ was observed in the investigated individuals. The total incidence of the haplotype with two substitutions (c.1055G/c.*96G haplotype) was found to be $9.4 \%$. One person was homozygous for these two alleles, and nine patients were heterozygous. The isolated substitution c. $1055 \mathrm{~A}>\mathrm{G}$ was revealed in two heterozygous individuals. No isolated substitution
$A$
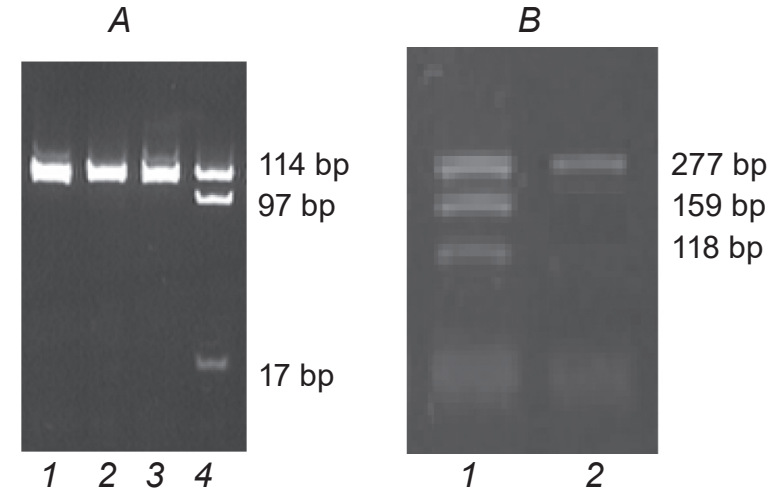

$A$ - allele c. ${ }^{*} 96 A>G$ of ARSA gene (1 - PCR fragment before restriction; 2-4 - PCR fragments after treatment with restriction endonuclease Ddel: 2,3wild type allele, $4-{ }^{*}$ allele $96 A>G$ heterozygous); $B$-allele c.1055A $>G$ of ARSA gene (PCR fragments after treatment with restriction endonuclease Bsrl: 1 - allele c.1055A $>$ G heterozygous; 2 - wild type allele) 
c. ${ }^{*} 96 \mathrm{~A}>\mathrm{G}$ was found in any of the cases. Thus, the total incidence of haplotypes, associated with the arylsulfatase A pseudodeficiency among the patients from Ukraine (c.1055G/c.*96G and c.1055G/c.*96A haplotypes) was $10.3 \%$.

Hexosaminidase A pseudodeficiency. Two substitutions, associated with hexosaminidase A pseudodeficiency, namely c.739C $>$ T (R247W) and c.745C $>\mathrm{T}$ (R249W), were described for the HEXA gene [4]. These substitutions were found in heterozygous carriers of pathogenic mutations in HEXA gene in all to date published cases. Therefore, to estimate the frequency of these alleles in Ukraine we exami ned 117 healthy donors and 14 heterozygous carriers of pathogenic mutations in HEXA gene (parents of children with the confirmed Tay-Sachs disease) for the presence of substitutions c.739C $>\mathrm{T}(\mathrm{R} 247 \mathrm{~W})$ and c.745C $>\mathrm{T}$ (R249W) in HEXA gene. No individual with at least one of the mentioned substitutions was found among the healthy volunteers. Among the carriers of pathogenic mutations in HEXA gene, there was one person (the father of a sick child) who had substitution c.739C $>$ T (R247W). Thus, the frequency of allele c.739C $>\mathrm{T}(\mathrm{R} 247 \mathrm{~W})$, associated with the hexosaminidase A pseudodeficiency, among the carriers of pathogenic mutations in HEXA gene in Ukraine was determined to be $7.1 \%$.

Acid $\alpha$-glucosidase pseudodeficiency. At present, the acid $\alpha$-glucosidase pseudodeficiency is associated with the substitutions c.1726G $>$ A (G576S) and c.2065G $>$ A (E689K) in GAA gene [18]. Similar to arylsulfatase A pseudodeficiency alleles, these alleles occur regardless of pathogenic mutations in the mentioned gene. Therefore, a group of 117 healthy volunteers was examined for the presence of these substitutions. The total incidence of alleles, associated with the $\alpha$-glucosidase pseudodeficiency, in our population was $0.43 \%$ for the substitution of c.1726G $>$ A and $1.28 \%$ for the substitution of c. $2065 \mathrm{G}>\mathrm{A}$. The distribution of genotypes among the investigated individuals corresponded to Hardy-Weinberg equilibrium for both substitutions $(P>0.05)$. Linkage disequilibrium of alleles c. $1726 \mathrm{G}>\mathrm{A}$ and c. $2065 \mathrm{G}>\mathrm{A}$ was less pronounced than that for the arylsulfatase A pseudodeficiency alleles $\left(r^{2}=0.33, p=0\right)$. The total frequency of the haplotype with two substitutions (1726A/2065A haplotype) was $0.9 \%$ (Table 3 ). One person was heterozygous for these two alleles. No isolated substitution c.1726G $>A$ was observed in any of the individuals, and isolated substitution c. $2065 \mathrm{G}>\mathrm{A}$ was found in two individuals, which is consistent with published data [21]. Thus, the total frequency of haplotypes, which cause the $\alpha$-glucosidase pseudodeficiency, among the individuals from Ukraine (1726A/2065A and 1726G/2065A haplotypes) was determined to be $2.6 \%$.

$\alpha$-Galactosidase and $\alpha$-iduronidase pseudodeficiency. The samples from 117 volunteers were investigated for the presence of the substitution c. $937 \mathrm{G}>\mathrm{T}(\mathrm{D} 313 \mathrm{Y})$ in GLA1 gene ( $\alpha$-galactosidase pseudodeficiency) and the substitution c. $898 \mathrm{G}>\mathrm{A}$ (A300T) in IDUA gene ( $\alpha$-iduronidase pseudodeficiency). No person with the mentioned substitutions was found among the examined individuals.

Arylsulfatase A is a lysosomal enzyme, a deficiency of which results in development of metachromatic leukodystrophy (MLD), a severe neurodegenerative disorder [1]. It was shown that the functionally active enzyme is produced in the cells of individuals with the arylsulfatase A pseudodeficiency, but it differs somewhat structurally from the normal one due to the loss of one of three oligosaccharide residues [3]. In most cases, the arylsulfatase A pseudodeficiency allele is a complex of two mutations in ARSA gene - c. $1055 \mathrm{~A}>\mathrm{G}$ and c. $* 96 \mathrm{~A}>\mathrm{G}$. The first one corresponds to the substitution N350S and substitutes asparagine for serine, impairing the glycosylation site. The second substitution $A>G$ in the position *96 impairs the work of polyadenylation signal.

Analyzing the obtained results on the distribution of the incidence of alleles c. $1055 \mathrm{~A}>\mathrm{G}$ and

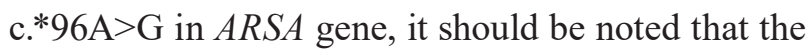
isolated substitution c. ${ }^{*} 96 \mathrm{~A}>\mathrm{G}$ does not practically occur in Ukraine, as in other European populations (Table 4) [8]. The total incidence of haplotypes associated with the arylsulfatase A pseudodeficiency in Ukraine is close to incidences, obtained by Middle European researchers.

The lowest incidence is observed in Finland, which is known for its peculiarities of gene incidences due to the demographic specificity of this country - a sparseness of first "settlers", the isolation due to low settlement density and geographic location. The highest incidence is in Portugal and Great Britain, which is close to the incidence of the arylsulfatase A pseudodeficiency allele in America (total incidence of haplotypes is about 0.2 ) and on the African continents (total incidence of haplotypes is $0.26-0.33)[8,22]$. This may be related to the great navigation history of these countries and the con- 


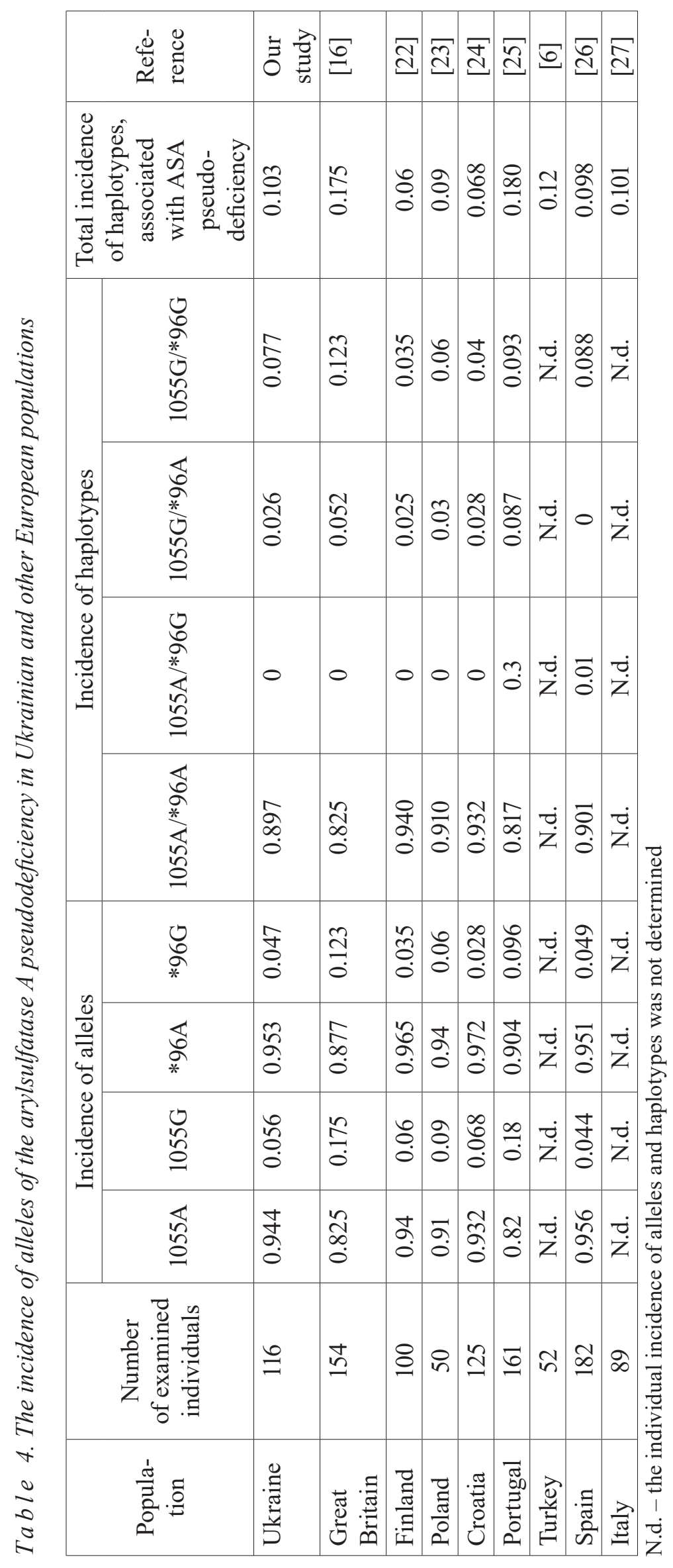


sequent migration of the population. The similarity between the incidences of the arylsulfatase A pseudodeficiency alleles in Ukraine, and those in Polish and Turkish populations may also be explained by the common centuries-long history and the population migration.

The deficiency in hexosaminidase A activity, which occurs due to the mutations in HEXA gene, usually results in Tay-Sachs disease [1]. However, there were described healthy individuals with pronounced deficiency of hexosaminidase A activity in vitro [4]. The vast majority of individuals with the pseudodeficiency of the mentioned enzyme had one of the polymorphic substitutions c.739C $>$ T (R247W) or c.745C $>\mathrm{T}$ (R249W) in the compound with pathogenic mutation in HEXA gene. This combination led to a considerable decrease in the hexosaminidase A activity regarding the 4-methylumbelliferyl-derived synthetic substrate $(0-25 \%$ of the control value), whereas the ability of this enzyme to hydrolyze the natural substrate was not impaired. The studies of the incidence of hexosaminidase A pseudodeficiency alleles demonstrated that about $2 \%$ of carriers of pathogenic mutations in HEXA gene among Ashkenazi Jews and $35 \%$ carriers of non-Jewish ethnicity had one of the polymorphic substitutions in the compound with the pathogenic mutation [4]. The incidence of the hexosaminidase A deficiency allele among the carriers of pathogenic mutations in HEXA gene from Ukraine was found to be $7.1 \%$. It should be noted that all the families with Tay-Sachs disease, examined by us, were of Ukrainian ethnicity. Thus, the determined incidence of the hexosaminidase A pseudodeficiency allele is related to the data for non-Jewish populations. Such high incidence of hexosaminidase A deficiency alleles among the carriers of pathogenic mutations in HEXA gene of non-Jewish ethnicity may lead to false-positive diagnosis of this disease.

The deficiency of lysosomal acid $\alpha$-glucosidase causes intralysosomal accumulation of glycogen, primarily in muscle tissues, that results in a severe progressive neuromuscular pathology - Pompe disease or type II glycogenesis [1].

In view of the introduction of enzyme replacement therapy of the disease into clinical practice, there is now urgency for early diagnostics for achievement maximized treatment efficiency. One of the approaches to early diagnostics of Pompe disease is the conducting of neonatal screening with the assessment of the acid $\alpha$-glucosidase activity in dry blood spot [21]. One of the difficulties in interpreting results of such a study is the described phenomenon of acid $\alpha$-glucosidase pseudodeficiency associated with two polymorphic substitutions in the $G A A$ gene - c. $1726 \mathrm{G}>\mathrm{A}(\mathrm{G} 576 \mathrm{~S})$ and c. $2065 \mathrm{G}>\mathrm{A}$ (E689K) [18]. It was demonstrated that the substitution c.1726 $\mathrm{G}>\mathrm{A}$ often occurs in the cis-position with the substitution c.2065 $\mathrm{G}>\mathrm{A}$, and leads to a considerable decrease in the acid $\alpha$-glucosidase activity, to practically pathological levels, in healthy individuals. In Asian population, the incidence of the acid $\alpha$-glucosidase pseudodeficiency allele is rather high $-3.3-3.9 \%$ of the total population [18]. The isolated substitution c. $2065 \mathrm{G}>$ A occurs with approximately the same incidence, whereas the isolated substitution c.1726G $>$ A was not found in any person. The information about the incidence of substitution, associated with acid $\alpha$-glucosidase pseudodeficiency in European populations is very limited (Table 5). There are only published data on the incidence of acid $\alpha$-glucosidase pseudodeficiency alleles in the Netherlands, which is very close to our results, in contrast to the very high incidence of these alleles among the population of Japan and China.

No substitution c.937G $>$ T (D313Y) in GLA1 gene ( $\alpha$-galactosidase pseudodeficiency) or substitution c.898G $>$ A (A300T) in IDUA gene ( $\alpha$-iduronidase pseudodeficiency) were found in any of the tested individuals. This indicates that the frequency of such mutations in Ukraine is smaller than 0.004, however, they may still be found. Therefore, in the process of diagnostics of Fabry disease and type I mucopolysaccharidosis, it is worth remembering that the presence of the mentioned mutations in patients requires obligatory further study to detect other disease-causing mutations.

Thus, taking into consideration the significant clinical polymorphism and genetic heterogeneity of lysosomal storage disorders, the differential diagnostics of this large group of hereditary diseases requires a wide application of different biochemical and molecular-genetic methods. At present, the assessment of the specific enzyme activity is a method of choice not only at the stage of confirming nosological diagnostics but also for examination of family members of the sick person with the purpose of medical and genetic consultation. Therefore, the results of the enzyme activity assessment should obligatorily be interpreted with consideration of the data about the presence or absence of the pseudodeficiency allele in the proband. According to our study, 


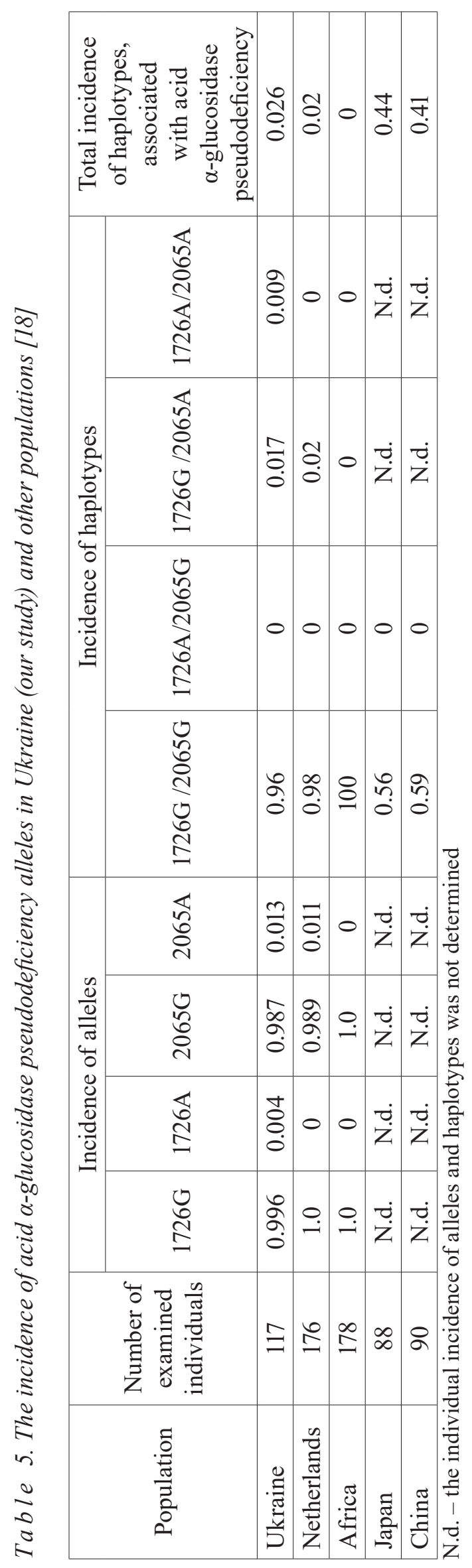

$10.3 \%$ of the Ukrainian population is carrier of the gene ARSA haplotypes associated with the arylsulfatase A pseudodeficiency, $2.6 \%$ of the population is carrier of acid $\alpha$-glucosidase pseudodeficiency alleles, and $7.1 \%$ of the carriers of pathogenic mutations in HEXA gene from Ukraine are carriers of the hexosaminidase A pseudodeficiency allele. Given a sufficiently high frequency of certain alleles in the total population of Ukraine, ignoring this phenomenon at biochemical analysis can lead to significant diagnostic errors.

\section{ВИЗНАЧЕННЯ ЧАСТОТИ \\ АЛЕЛІВ, ПОВ'ЯЗАНИХ ІЗ ПСЕВДОДЕФІЦИТОМ ЛІЗОСОМНИХ ГІДРОЛАЗ, СЕРЕД НАСЕЛЕННЯ УКРАЇНИ}

\section{Н. В. Ольхович, Н. Г. Горовенко}

\section{ДУ Інститут генетичної та регенеративної медицини НАМН України, Київ; e-mail: e-mail: nolhovich@gmail.com}

Псевдодефіцит активності лізосомних гідролаз, описаний як істотне зниження ензиматичної активності in vitro у клінічно здорових осіб, загрожує діагностичними помилками за біохімічної діагностики лізосомних хвороб накопичення в разі його поєднання 3 патологією іншого генезу. У більшості випадків псевдодефіцит обумовлений певними непатогенними змінами у відповідному гені, які призводять до лабільності ензиматичної молекули in vitro, тоді як in vivo ензим зберігає функціональну активність. Для оцінки поширеності найрозповсюдженіших алелів псевдодефіциту лізосомних гідролаз в Україні нами було визначено частоту алелів с.1055A $>\mathrm{G}$ i c. ${ }^{* 96 \mathrm{~A}}>\mathrm{G}$ в гені ARSA, а також замін с.739C $>\mathrm{T}$ (R247W) та c.745C $>\mathrm{T}$ (R249W) в гені HEXA, c.1726G $>$ A (G576S) та с.2065G $>$ A (E689K) в гені $G A A$, c.937G $>$ T (D313Y) в гені GLA1 та с.898G $>\mathrm{A}$ (А300T) у гені IDUA серед 117 здорових осіб із різних регіонів країни та 14 гетерозиготних носіїв патогенних мутацій в гені HEXA (батьки дітей 3 підтвердженим діагнозом хвороби Тея-Сакса). Сумарна частота гаплотипів, які обумовлюють псевдодефіцит арилсульфатази А у здорових осіб (c.1055G/c.*96G та c.1055G/c.*96А гаплотипи), дорівнювала 10,3\%. Частота алеля с.739C $>\mathrm{T}$ $(\mathrm{R} 247 \mathrm{~W})$, асоційованого 3 псевдодефіцитом 
гексозамінідази А, серед носіїв патогенних мутацій в гені $H E X A$ з України становила 7,1\%. Сумарна частота гаплотипів, які обумовлюють псевдодефіцит $\alpha$-глюкозидази в здорових осіб (1726A/2065A та $1726 \mathrm{G} / 2065 \mathrm{~A}$ гаплотипи), становила 2,6\%. Серед обстежених волонтерів, які б мали заміни с.937G $>$ T (D313Y) у гені GLA1 та c.898G $>$ A (А300T) у гені IDUA жодної особи не виявлено.

Зроблено висновок, що інтерпретацію результатів визначення ензиматичної активності у разі біохімічної діагностики лізосомних хвороб накопичення необхідно проводити 3 урахуванням даних про наявність або відсутність у пробанда алеля псевдодефіциту. Якщо враховувати досить велику частоту деяких алелів у загальній популяції, то ігнорування цього явища може призвести до значних діагностичних помилок.

К л ю чов і с лов а: лізосомні гідролази, псевдодефіцит ензиматичної активності, частота алелів.

\section{ОПРЕДЕЛЕНИЕ ЧАСТОТЫ АЛЛЕЛЕЙ, СВЯЗАННЫХ С ПСЕВДОДЕФИЦИТОМ ЛИЗОСОМНЫХ ГИДРОЛАЗ, СРЕДИ НАСЕЛЕНИЯ УКРАИНЫ}

\section{Н. В. Ольхович, Н. Г. Горовенко}

\section{ГУ Институт генетической и регенеративной медицины НАМН Украины, Киев; e-mail: e-mail: nolhovich@gmail.com}

Псевдодефицит активности лизосомных гидролаз, описанный как существенное снижение энзиматической активности in vitro y клинически здоровых лиц, грозит диагностическими ошибками в ходе биохимической диагностики лизосомных болезней накопления при его сочетании с патологией иного генеза. В большинстве случаев псевдодефицит обусловлен определенными непатогенными изменениями в соответствующем гене, которые приводят к лабильности энзиматической молекулы in vitro, тогда как in vivo энзим сохраняет функциональную активность. Для оценки распространенности наиболее частых аллелей псевдодефицита лизосомных гидролаз в Украине определяли частоту аллелей с.1055A> G и c. ${ }^{*} 96 \mathrm{~A}>\mathrm{G}$ в гене $A R S A$, а также замен с.739C>
$\mathrm{T}(\mathrm{R} 247 \mathrm{~W})$ и с.745C $>\mathrm{T}(\mathrm{R} 249 \mathrm{~W})$ в гене HEXA, c. $1726 \mathrm{G}>\mathrm{A}(\mathrm{G} 576 \mathrm{~S})$ и с. $2065 \mathrm{G}>\mathrm{A}(\mathrm{E} 689 \mathrm{~K})$ в гене $G A A$, c. $937 \mathrm{G}>\mathrm{T}(\mathrm{D} 313 \mathrm{Y})$ в гене $G L A 1$ и с. $898 \mathrm{G}>\mathrm{A}$ (A300T) в гене IDUA среди 117 здоровых человек из разных регионов и 14 гетерозиготных носителей патогенных мутаций в гене $H E X A$ (родители детей с подтвержденным диагнозом болезни Тея-Сакса). Суммарная частота гаплотипов, которые обусловливают псевдодефицит арилсульфатазы А у здоровых лиц (с.1055G/c.*96G и c. $1055 \mathrm{G} / \mathrm{c} .{ }^{*} 96 \mathrm{~A}$ гаплотипы), составила $10,3 \%$. Частота аллеля c.739C $>\mathrm{T}$ (R247W), ассоциированного с псевдодефицитом гексозаминидазы $\mathrm{A}$, среди носителей патогенных мутаций в гене $H E X A$ из Украины составила 7,1\%. Суммарная частота гаплотипов, которые обусловливают псевдодефицит $\alpha$-глюкозидазы у здоровых лиц (1726A/2065A и $1726 \mathrm{G} / 2065 \mathrm{~A}$ гаплотипы), равнялась 2,6\%. Среди обследованных волонтеров, которые имели бы замены c.937G $>$ T (D313Y) в гене GLA1 и замены с.898G $>\mathrm{A}$ (А300T) в гене $I D U A$ не найдено ни одного человека.

Сделан вывод, что интерпретацию результатов определения энзиматической активности при проведении биохимической диагностики лизосомных болезней накопления необходимо проводить с учетом данных о наличии или отсутствии у пробанда аллеля псевдодефицита. Если учитывать достаточно большую частоту некоторых аллелей в общей популяции, то игнорирование этого явления может привести к значительным диагностическим ошибкам.

К л ю чев ы е с лов а: лизосомные гидролазы, псевдодефицит энзиматической активности, частота аллелей.

\section{References}

1. Mehta A., Winchester B. Lysosomal storage disorders: a practical guide. London: WileyBlackwell, 2012. P. 38-46.

2. Thomas GH. "Pseudodeficiencies" of lysosomal hydrolases. Am J Hum Genet. 1994; 54(6): 934940.

3. Gieselmann V, Polten A, Kreysing J, von Figura K. Arylsulfatase A pseudodeficiency: loss of a polyadenylylation signal and N-glycosylation site. Proc Natl Acad Sci USA. 1989; 86(23): 9436-9440.

4. Park NJ, Morgan C, Sharma R, Li Y, Lobo RM, Redman JB, Salazar D, Sun W, Neidich JA, Strom CM. Improving accuracy of Tay Sachs 
carrier screening of the non-Jewish population: analysis of 34 carriers and six late-onset patients with HEXA enzyme and DNA sequence analysis. Pediatr Res. 2010; 67(2): 217-220.

5. Lugowska A, Czartoryska B, Tylki-Szymańska A, Bisko M, Zimowski JG, Berger J, Molzer B. Prevalence of arylsulfatase A pseudodeficiency allele in metachromatic leukodystrophy patients from Poland. Eur Neurol. 2000; 44(2): 104-107.

6. Emre S, Topçu M, Terzioğlu M, Renda Y. Arylsulfatase A pseudodeficiency incidence in Turkey. Turk J Pediatr. 2000; 42(2): 115-117.

7. Gorovenko NG, Olkhovich NV. Differentiation between arylsulfatase A deficiency and pseudodeficiency. Ukr Biokhim Zhurn. 2003; 75(5): 106-111. (In Ukrainian).

8. Ben Halim N, Dorboz I, Kefi R, Kharrat N5, Eymard-Pierre E, Nagara M, Romdhane L, Ben Alaya-Bouafif N, Rebai A, Miladi N, BoespflugTanguy O, Abdelhak S. Determination of arylsulfatase A pseudodeficiency allele and haplotype frequency in the Tunisian population. Neurol Sci. 2016; 37(3): 403-409.

9. Shukla P, Vasisht S, Srivastava R, Gupta N, Ghosh M, Kumar M, Sharma R, Gupta AK, Kaur P, Kamate M, Gulati S, Kalra V, Phadke S, Singhi P, Dherai AJ, Kabra M. Molecular and structural analysis of metachromatic leukodystrophy patients in Indian population. J Neurol Sci. 2011; 301(1-2): 38-45.

10. Virgens MY, Siebert M, Bock H, Burin M, Giugliani R, Saraiva-Pereira ML. Genotypic characterization of Brazilian patients with infantile and juvenile forms of metachromatic leukodystrophy. Gene. 2015; 568(1): 69-75.

11. Han M, Jun SH, Lee YJ, Eun BL, Lee SJ, Seong MW, Park SS, Song SH, Park HD, Song J. Biochemical and Genetic Analysis of Seven Korean Individuals With Suspected Metachromatic Leukodystrophy. Ann Lab Med. 2015; 35(4): 458-462.

12. Dlott B, d'Azzo A, Quon DV, Neufeld EF. Two mutations produce intron insertion in mRNA and elongated beta-subunit of human betahexosaminidase. J Biol Chem. 1990; 265(29): 17921-17927.

13. Sabourdy F, Labauge P, Stensland HM, Nieto M, Garcés VL, Renard D, Castelnovo G, de Champfleur N, Levade T. A MANBA mutation resulting in residual beta-mannosidase activity associated with severe leukoencephalopathy: a possible pseudodeficiency variant. BMC Med Genet. 2009; 10: 84.

14. Gort L, Santamaria R, Grinberg D, Vilageliu L, Chabás A. Identification of a novel pseudodeficiency allele in the GLB1 gene in a carrier of GM1 gangliosidosis. Clin Genet. 2007; 72(2): 109-111.

15. Gieselmann V, Zlotogora J, Harris A, Wenger DA, Morris CP. Molecular genetics of metachromatic leukodystrophy. Hum Mutat. 1994; 4(4): 233-242.

16. Barth ML, Ward C, Harris A, Saad A, Fensom A. Frequency of arylsulphatase A pseudodeficiency associated mutations in a healthy population. J Med Genet. 1994; 31(9): 667-671.

17. Zlotogora J, Gieselman V, von Figura $\mathrm{K}$, Zeigler M, Bach G. Late infantile metachromatic leukodystrophy in Israel. Biomed Pharmacother. 1994; 48(8-9): 347-350.

18. Kroos MA, Mullaart RA, Van Vliet L, Pomponio RJ, Amartino $\mathrm{H}$, Kolodny $\mathrm{EH}$, Pastores GM, Wevers RA, Van der Ploeg AT, Halley DJ, Reuser AJ. p.[G576S; E689K]: pathogenic combination or polymorphism in Pompe disease? Eur J Hum Genet. 2008; 16(8): 875-879.

19. Yasuda M, Shabbeer J, Benson SD, Maire I, Burnett RM, Desnick RJ. Fabry disease: characterization of alpha-galactosidase A double mutations and the D313Y plasma enzyme pseudodeficiency allele. Hum Mutat. 2003; 22(6): 486-492.

20. Aronovich EL, Pan D, Whitley CB. Molecular genetic defect underlying alpha-L-iduronidase pseudodeficiency. Am J Hum Genet. 1996; 58(1): 75-85.

21. Labrousse P, Chien YH, Pomponio RJ, Keutzer J, Lee NC, Akmaev VR, Scholl T, Hwu WL. Genetic heterozygosity and pseudodeficiency in the Pompe disease newborn screening pilot program. Mol Genet Metab. 2010; 99(4): 379383.

22. Ricketts MH, Goldman D, Long JC, Manowitz P. Arylsulfatase A pseudodeficiency-associated mutations: population studies and identification of a novel haplotype. Am J Med Genet. 1996; 67(4): 387-392.

23. Czartoryska B, Zimowski JG, Bisko M, Górska D. Arylsulfatase A pseudodeficiency-incidence in Poland. Eur J Hum Genet. 1996; 4(5): 301-303. 
24. Bognar SK, Furac I, Kubat M, Cosović C, Demarin V. Croatian population data for arylsulfatase a pseudodeficiency-associated mutations in healthy subjects, and in patients with Alzheimer-type dementia and Down syndrome. Arch Med Res. 2002; 33(5): 473-477.

25. Marcão A, Pinto E, Rocha S, Sá Miranda MC, Ferreira L, Amaral O. ARSA-PD associated alleles in the Portuguese population: frequency determination and haplotype analysis. Mol Genet Metab. 2003; 79(4): 305-307.
26. Gort L, Coll MJ, Chabás A. Identification of 12 novel mutations and two new polymorphisms in the arylsulfatase A gene: haplotype and genotype-phenotype correlation studies in Spanish metachromatic leukodystrophy patients. Hum Mutat. 1999; 14(3): 240-248.

27. Regis S, Filocamo M, Stroppiano M, Corsolini F, Gatti R. Molecular analysis of the arylsulphatase A gene in late infantile metachromatic leucodystrophy patients and healthy subjects from Italy. J Med Genet. 1996; 33(3): 251-252.

Received 20.05.2016 